\title{
Reduction of Benzyl Viologen Distinguishes Genera of the Class Mollicutes
}

\author{
J. DENNIS POLLACK, ${ }^{1 *}$ JONATHAN BANZON, ${ }^{1}$ KELLY DONELSON,${ }^{1}$ JOSEPH G. TULLY, ${ }^{2}$ \\ JOHN W. DAVIS, JR., ${ }^{3}$ KEVIN J. HACKETT, ${ }^{4}$ CALISTA AGBANYIM, ${ }^{5}$ \\ AND ROGER J. MILES ${ }^{5}$
}

Department of Medical Microbiology and Immunology, The Ohio State University, Columbus, Ohio 43210'; Mycoplasma Section, National Institute of Allergy and Infectious Diseases, Frederick Cancer Research Facility, Frederick, Maryland 217022; Department of Biology and Medical Laboratory Technology, Bronx Community College-City University of New York, Bronx, New York 104533; Insect Biocontrol Laboratory, Agricultural Research Service, U.S. Department of Agriculture, Beltsville, Maryland 207054; and Division of Life Sciences, Kings College, University of London, London W8 7AH, England ${ }^{5}$

\begin{abstract}
We tested the ability of 62 growing strains belonging to the class Mollicutes to reduce the redox indicator and free-radical generator 1,1'-dibenzyl-4,4' -bipyridinium dichloride (benzyl viologen [BV]) to a blue-violet-purple color. BV was reduced by 12 Acholeplasma species but not by Acholeplasma multiforme $\operatorname{PN525}^{\mathrm{T}}$ ( $\mathrm{T}=$ type strain). BV was also reduced by five of nine Mesoplasma species and by four of six Entomoplasma species. BV was not reduced by 19 Mycoplasma species, six Spiroplasma species, five unnamed Spiroplasma strains belonging to different serogroups, three Ureaplasma species, and one unnamed Ureaplasma strain. The BV-reducing ability was localized in the membrane of Acholeplasma laidlawii B-PG9 and was dependent on NADH. Reduction of BV could be expressed in mixed cultures, and this activity may be useful for recognizing the contaminating presence of an Acholeplasma species. The reductive BV response may have phylogenetic value. We believe that the test described in this paper readily distinguishes all Acholeplasma species and some Mesoplasma and Entomoplasma species from all Mycoplasma, Spiroplasma, and Ureaplasma species tested.
\end{abstract}

The use of redox indicators like tetrazolium salts to study the wall-less members of the class Mollicutes was first described by Somerson and Morton (19). There have been numerous applications of the observation of these authors $(1,4,8,17)$. Although most members of the Mollicutes have been found to reduce tetrazolium salts $(8,21)$, this characteristic is now thought to have little value in identification or in the development of a taxonomy for the Mollicutes (20). Nevertheless, the use of tetrazolium salts to monitor the growth kinetics and metabolism of these organisms is still a valuable experimental and clinical tool $(8,18)$. Besides tetrazolium salts there are other redox indicators that may be useful in distinguishing and characterizing Mollicutes. Among the indicators that we examined were the bipyridinium compounds $1,1^{\prime}$-dibenzyl-4,4'-bipyridinium dichloride (benzyl viologen [BV] and methyl viologen (paraquat). In this study of 62 strains belonging to the Mollicutes, we found that BV added to broth cultures of members of the non-cholesterol-requiring Mollicutes genus Acholeplasma underwent a rapid and profound color change. There are six genera of facultatively anaerobic Mollicutes, and the response which we describe below distinguished the members of the genus Acholeplasma from all Mycoplasma, Spiroplasma, and Ureaplasma species and most Mesoplasma and Entomoplasma species tested.

\section{MATERIALS AND METHODS}

Mollicutes, growth media, and culture conditions. The members of the $\mathrm{Mol}$ licutes that we studied are listed in Table 1 . It was necessary to employ a number of different media to grow the members of the six facultatively anaerobic $\mathrm{Mol}$ licutes genera that were studied. Two of the media were variations of modified

* Corresponding author. Mailing address: Department of Medical Microbiology and Immunology, The Ohio State University, 333 West 10th Ave., Columbus, OH 43210. Phone: (614) 292-8352. Fax: (614) 292-9805. Electronic mail address: pollack.1@osu.edu.
Edward's medium. One of these media was called SNE (Table 1) and contained (per liter) $20 \mathrm{~g}$ of Mycoplasma Broth Base (BBL), $2 \mathrm{~g}$ of Bacto Yeast Extract (Difco Laboratories), $11 \mathrm{~g}$ of $N$-2-hydroxyethylpiperazine- $N^{\prime}$-2-ethanesulfonic acid (HEPES) (Research Organics, Inc., Cleveland, Ohio), $10 \mathrm{~g}$ of Bacto Peptone, (Difco), and $0.1 \mathrm{~g}$ of herring sperm DNA (Sigma); the final $\mathrm{pH}$ was 7.6 . After this basal broth had been autoclaved, we added (per liter) $14 \mathrm{ml}$ of a separately autoclaved $50 \%(\mathrm{wt} / \mathrm{vol})$ glucose solution and $6 \mathrm{ml}$ of a separately autoclaved $41 \%$ (wt/vol) anhydrous $\mathrm{K}_{2} \mathrm{HPO}_{4}$ solution. Horse serum (Hyclone or Oxoid) was added to a concentration of $10 \%$ ( $\mathrm{vol} / \mathrm{vol})$. The second variation of modified Edward's medium was not autoclaved. This medium was similar to SNE; however, PPLO Broth w/o CV (Difco) was used instead of Mycoplasma Broth Base, peptone was omitted, the level of yeast extract was $5 \mathrm{~g} /$ /iter, the concentration of horse serum (GIBCO) was only $3.0 \%(\mathrm{wt} / \mathrm{vol})$ and $1.8 \mathrm{~g}$ of "ultrapure" urea (Research Organics, Inc.) per liter was added. The ingredients of this medium were combined with distilled water, and the $\mathrm{pH}$ was adjusted to 7.4 with $2 \mathrm{~N} \mathrm{NaOH}$. The solution was clarified by sequential filtration through 1.2 - and $0.45-\mu \mathrm{m}$-pore-size filters and then sterilized by passage through a 0.2 $\mu \mathrm{m}$-pore-size filter. This medium was called MEM+U (Table 1) and was used exclusively for the growth of all Ureaplasma isolates.

To grow Spiroplasma species, we used the following three media (Table 1): BSR (3), M1D (23), and H-2 (6). The growth medium and incubation temperature used for each Mollicutes strain are shown in Table 1.

In the experimental assay to determine growth reduction of BV, a filtersterilized aqueous solution ( $50 \mathrm{mM}$ ) of BV (Sigma) was added to tubes containing sterile medium to a final concentration of $1 \mathrm{mM}$. As the reduced BV was readily reoxidized by air and thereby decolorized, the tubes were filled with 5 to $10 \mathrm{ml}$ of medium as the generally preferred configuration. In some experiments, to impede the diffusion of air and reduce reoxidation, 1.5 to $2 \mathrm{~cm}$ of sterile (autoclaved) mineral oil (USP) was added as an overlay after inoculation. The stock solution of $\mathrm{BV}$ and media containing $\mathrm{BV}$ were stored at $4^{\circ} \mathrm{C}$ for several months with no apparent loss of activity.

With the exception of the ureaplasmas, cultures were incubated for 10 to 14 days depending on the isolate, before they were characterized as BV negative. The animal Ureaplasma isolates were subcultured only three times. Ureaplasma urealyticum $\mathrm{T} 960^{\mathrm{T}}(\mathrm{T}=$ type strain) was subcultured seven times. Mollicutes strains that were always capable of reducing BV within five to seven consecutive transfers were considered BV positive. Mollicutes cultures in which no reduction of BV occurred were subcultured with fresh BV-containing medium for 4 to 12 consecutive transfers. Only if all of the resulting cultures failed to reduce BV were the isolates considered $\mathrm{BV}$ negative.

Other assays. In order to identify the cellular localization of the BV-reducing ability, membrane and cytoplasmic fractions of Acholeplasma laidlawii B-PG9 were prepared by osmotic shock as previously described (12). The reduction of 
TABLE 1. BV reduction by members of the class Mollicutes

\begin{tabular}{|c|c|c|c|}
\hline Organism & Response $^{a}$ & $\begin{array}{l}\text { Growth } \\
\text { medium } \\
\text { containing } \\
1 \mathrm{mM} \mathrm{BV}\end{array}$ & $\begin{array}{l}\text { Growth } \\
\text { temp } \\
\left({ }^{\circ} \mathrm{C}\right)\end{array}$ \\
\hline Acholeplasma axanthum S-743 ${ }^{\mathrm{T}}$ & + & SNE & 37 \\
\hline Acholeplasma brassicae $0502^{\mathrm{T}}$ & + & SNE & 37 \\
\hline Acholeplasma cavigenitalium $\mathrm{GP}^{\mathrm{T}}$ & + & SNE & 37 \\
\hline Acholeplasma equifetale $\mathrm{C} 112^{\mathrm{T}}$ & + & SNE & 37 \\
\hline Acholeplasma granularum BTS $-39^{\mathrm{T}}$ & + & SNE & 37 \\
\hline Acholeplasma hippikon $\mathrm{C}^{\mathrm{T}}$ & + & SNE & 37 \\
\hline Acholeplasma laidlawii $\mathrm{PG}^{\mathrm{T}}$ & + & SNE & 37 \\
\hline Acholeplasma modicum $\mathrm{PG} 49^{\mathrm{T}}$ & + & SNE & 37 \\
\hline Acholeplasma morum $72-043^{\mathrm{T}}$ & + & SNE & 37 \\
\hline Acholeplasma multilocale PN $525^{\mathrm{T}}$ & - & SNE & 37 \\
\hline Acholeplasma oculi $19 \mathbf{L}^{\mathrm{T}}$ & + & SNE & 37 \\
\hline Acholeplasma palmae $\mathbf{J} 233^{\mathrm{T}}$ & + & SNE & 37 \\
\hline Acholeplasma parvum $\mathrm{H} 23 \mathrm{~N}^{\mathrm{T}}$ & + & SNE & 37 \\
\hline $\begin{array}{l}\text { Mycoplasma alkalescens PG51 } \\
\quad\left(=\text { NCTC } 10135^{\mathrm{T}}\right)\end{array}$ & - & SNE & 37 \\
\hline $\begin{array}{l}\text { Mycoplasma arginini } \mathrm{G} 230^{\mathrm{T}} \\
\left(=\text { NCTC } 10129^{\mathrm{T}}\right)\end{array}$ & - & SNE & 37 \\
\hline $\begin{array}{l}\text { Mycoplasma bovis } \text { PG } 45^{\mathrm{T}} \\
\left(=\text { NCTC } 10131^{\mathrm{T}}\right)\end{array}$ & - & SNE & 37 \\
\hline $\begin{array}{l}\text { Mycoplasma bovoculi M165/69 } \\
\left(=\text { NCTC } 10141^{\mathrm{T}}\right)\end{array}$ & - & SNE & 37 \\
\hline $\begin{array}{l}\text { Mycoplasma buccale } \mathrm{CH} 20247^{\mathrm{T}} \\
\left(=\mathrm{NCTC} 10136^{\mathrm{T}}\right)\end{array}$ & - & SNE & 37 \\
\hline $\begin{array}{l}\text { Mycoplasma califormicum ST- } 6^{\mathrm{T}} \\
\left(=\text { NCTC } 10189^{\mathrm{T}}\right)\end{array}$ & - & SNE & 37 \\
\hline $\begin{array}{l}\text { Mycoplasma capricolum subsp. } \\
\text { capricolum California } \mathrm{Kid}^{\mathrm{T}} \\
\left(=\text { NCTC } 10154^{\mathrm{T}}\right)\end{array}$ & - & SNE & 37 \\
\hline $\begin{array}{l}\text { Mycoplasma fermentans PG18 } \\
\left(=\text { NCTC } 10177^{\mathrm{T}}\right)\end{array}$ & - & SNE & 37 \\
\hline $\begin{array}{l}\text { Mycoplasma felis } \mathrm{CO}^{\mathrm{T}} \\
\quad\left(=\text { NCTC } 10160^{\mathrm{T}}\right)\end{array}$ & - & SNE & 37 \\
\hline $\begin{array}{l}\text { Mycoplasma flocculare Ms } 42^{\mathrm{T}} \\
\left(=\text { NCTC } 10143^{\mathrm{T}}\right)\end{array}$ & - & SNE & 37 \\
\hline $\begin{array}{l}\text { Mycoplasma gallinarum PG16 } \\
\left(=\text { NCTC } 10120^{\mathrm{T}}\right)\end{array}$ & - & SNE & 37 \\
\hline $\begin{array}{l}\text { Mycoplasma gallisepticum PG31 } \\
\quad\left(=\text { NCTC } 10115^{T}\right)\end{array}$ & - & SNE & 37 \\
\hline $\begin{array}{l}\text { Mycoplasma hyopneumoniae } \mathbf{J}^{\mathrm{T}} \\
\quad\left(=\text { NCTC } 10110^{\mathrm{T}}\right)\end{array}$ & - & SNE & 37 \\
\hline $\begin{array}{l}\text { Mycoplasma imitans } 4229^{\mathrm{T}} \\
\left(=\text { NCTC } 11733^{\mathrm{T}}\right)\end{array}$ & - & SNE & 37 \\
\hline $\begin{array}{l}\text { Mycoplasma penetrans GTU-54-6A1 }{ }^{\mathrm{T}} \\
\quad\left(=\text { ATCC } 55252^{\mathrm{T}}\right)\end{array}$ & - & SNE & 37 \\
\hline $\begin{array}{l}\text { Mycoplasma pirum HRC70-159 } \\
\quad\left(=\text { NCTC } 11702^{\mathrm{T}}\right)\end{array}$ & - & SNE & 37 \\
\hline $\begin{array}{l}\text { Mycoplasma primatum } \mathrm{HRC} 292^{\mathrm{T}} \\
\left(=\mathrm{NCTC} 10163^{\mathrm{T}}\right)\end{array}$ & - & SNE & 37 \\
\hline $\begin{array}{l}\text { Mycoplasma salivarium } \mathrm{PG} 20^{\mathrm{T}} \\
\left(=\text { NCTC } 10113^{\mathrm{T}}\right)\end{array}$ & - & SNE & 37 \\
\hline $\begin{array}{l}\text { Mycoplasma verrecundum } 107^{\mathrm{T}} \\
\quad\left(=\text { NCTC } 10145^{\mathrm{T}}\right)\end{array}$ & - & SNE & 37 \\
\hline Spiroplasma apis $\mathrm{B} 31^{\mathrm{T}}$ & - & BSR & 32 \\
\hline Spiroplasma citri $\mathrm{R} 8 \mathrm{~A} 2 \mathrm{Maroc}^{\mathrm{T}}$ & - & BSR & 30 \\
\hline Spiroplasma citri $\mathrm{R} 8 \mathrm{~A} 2 \mathrm{Maroc}^{\mathrm{T}}$ & - & M1D & 32 \\
\hline Spiroplasma clarkii $\mathrm{CN}-5^{\mathrm{T}}$ & - & BSR & 32 \\
\hline Spiroplasma diabroticae $\mathrm{DU}-\mathrm{1}^{\mathrm{T}}$ & - & BSR & 32 \\
\hline Spiroplasma ixodetis $\mathrm{Y}^{2} 2^{\mathrm{T}}$ & - & M1D & 26,32 \\
\hline Spiroplasma ixodetis $\mathrm{Y}^{2} 2^{\mathrm{T}}$ & - & BSR & 32 \\
\hline Spiroplasma ixodetis $\mathrm{Y}^{2} 2^{\mathrm{T}}$ & - & $\mathrm{H}-2$ & 32 \\
\hline Spiroplasma leptinotarsae $\mathrm{LD}-1^{\mathrm{T}}$ & - & $\mathrm{H}-2$ & 32 \\
\hline Spiroplasma mirum $\mathrm{SMCA}^{T}$ & - & M1D & 32 \\
\hline Spiroplasma monobiae MQ-1 ${ }^{\mathrm{T}}$ & - & BSR & 32 \\
\hline Spiroplasma taiwanense $\mathrm{CT}-1^{\mathrm{T}}$ & - & BSR & 32 \\
\hline
\end{tabular}

TABLE $1-$ Continued

\begin{tabular}{|c|c|c|c|}
\hline Organism & Response $^{a}$ & $\begin{array}{c}\text { Growth } \\
\text { medium } \\
\text { containing } \\
1 \mathrm{mM} \mathrm{BV}\end{array}$ & $\begin{array}{l}\text { Growth } \\
\text { temp } \\
\left({ }^{\circ} \mathrm{C}\right)\end{array}$ \\
\hline Spiroplasma group II strain DW-1 & - & BSR & 32 \\
\hline Spiroplasma group XXIII strain TG-1 & - & BSR & 32 \\
\hline Ureaplasma diversum $\mathrm{T} 44$ & - & $\mathrm{MEM}+\mathrm{U}$ & 37 \\
\hline $\begin{array}{l}\text { Ureaplasma gallorale D6-1 } \\
\quad\left(=\text { ATCC } 43346^{\mathrm{T}}\right)\end{array}$ & - & $\mathrm{MEM}+\mathrm{U}$ & 37 \\
\hline Ureaplasma urealyticum $\mathrm{T} 960^{\mathrm{T}}$ & - & $\mathrm{MEM}+\mathrm{U}$ & 37 \\
\hline Ureaplasma urealyticum $\mathrm{Pi}$ & - & $\mathrm{MEM}+\mathrm{U}$ & 37 \\
\hline Ureaplasma sp. ovine strain 1692 & - & $\mathrm{MEM}+\mathrm{U}$ & 37 \\
\hline Mesoplasma chauliocola CHPA- $2^{\mathrm{T}}$ & + & SNE & 30 \\
\hline Mesoplasma entomophilum $\mathrm{TAC}^{\mathrm{T}}$ & - & SNE & 30 \\
\hline Mesoplasma flonum $\mathrm{L}^{\mathrm{T}}$ & $\begin{array}{c}\text { Weak, } \\
\text { variable }^{b}\end{array}$ & SNE & 30 \\
\hline Mesoplasma florum $\mathrm{GF}$ & $\begin{array}{l}\text { Weak, } \\
\text { variable }^{b}\end{array}$ & SNE & 30 \\
\hline Mesoplasma grammopteriae GRUA-1 ${ }^{\mathrm{T}}$ & + & SNE & 30 \\
\hline Mesoplasma lactucae 831-C4 $4^{\mathrm{T}}$ & - & SNE & 30 \\
\hline Mesoplasma pleciae $\mathrm{PS}-1^{\mathrm{T}}$ & + & SNE & 30 \\
\hline Mesoplasma seiffertii $\mathrm{F} 7^{\mathrm{T}}$ & - & SNE & 30 \\
\hline Mesoplasma syrphidae $\mathrm{YJS}^{\mathrm{T}}$ & - & SNE & 30 \\
\hline Mesoplasma tabanidae BARC $857^{\mathrm{T}}$ & + & SNE & 30 \\
\hline Entomoplasma ellychniae ELCN $-1^{\mathrm{T}}$ & - & SNE & 30 \\
\hline Entomoplasma lucivorax $\mathrm{PIPN}-2^{\mathrm{T}}$ & - & SNE & 30 \\
\hline Entomoplasma luminosum $\mathrm{PIMN}-1^{\mathrm{T}}$ & - & SNE & 30 \\
\hline Entomoplasma melaleucae $\mathrm{M}-1^{\mathrm{T}}$ & Variable $^{b}$ & SNE & 30 \\
\hline Entomoplasma somnilux PYAN-1 ${ }^{\mathrm{T}}$ & - & SNE & 30 \\
\hline
\end{tabular}

$a+$, blue-violet-purple coloration of the medium appeared within 4 to $48 \mathrm{~h}$ at 30.0 or $37.0^{\circ} \mathrm{C}$ and in all five to seven subcultures; -, no coloration of the medium occurred during 3 to 12 consecutive subcultures.

${ }^{b}$ Blue-violet-purple coloration of the medium was observed discontinuously during 9 or 10 consecutive subcultures.

BV by membranes was monitored spectrophotometrically at $555 \mathrm{~nm}$. Each reaction mixture (final volume, $1 \mathrm{ml}$ ) contained $50 \mathrm{mM}$ HEPES (pH 7.4), $155 \mathrm{mM}$ $\mathrm{NaCl}, 1 \mathrm{mM} 2$-mercaptoethanol, and 20 to $300 \mu \mathrm{g}$ of cell membrane protein. The reaction was started by adding NADH to a final concentration of $5.2 \mathrm{mM}$. Protein contents were determined by using the Bio-Rad standard microassay and bovine serum albumin as the protein standard.

\section{RESULTS}

Table 1 shows the ability of 62 members of the Mollicutes representing the six facultatively anaerobic genera in the class to reduce BV during growth. Twelve Acholeplasma species but not Acholeplasma multilocale PN525 were BV positive. Of the nine Mesoplasma species studied, four were always BV positive, and another (Mesoplasma florum) was weakly reductive (consecutive subcultures were not consistently BV positive). Four mesoplasmas were BV negative. Five Entomoplasma species were examined; one was variable like Mesoplasma florum, and four were BV negative. Nineteen Mycoplasma species, seven Spiroplasma species, five Spiroplasma strains representing four other different serogroups, three Ureaplasma species, and two other Ureaplasma strains were all BV negative.

With most Acholeplasma species a blue-violet-purple color appeared within $12 \mathrm{~h}$, but with $A$. laidlawii B-PG9 the color appeared within 4 to $5 \mathrm{~h}$. The color generally filled the growth tubes, making them almost completely opaque. After shaking, aeration, or prolonged incubation the color disappeared. Cultures were examined frequently during the first $24 \mathrm{~h}$.

The $\lambda_{\max }$ of the blue-violet-purple color in BV-positive cultures was 553 to $556 \mathrm{~nm}$, and the color was lost upon aeration. 
We were also able to reproduce the color response in a mixture containing $1 \mathrm{mM} \mathrm{BV}$ and $0.1 \mathrm{mM}$ sodium borohydride in distilled water. The $\lambda_{\max }$ of this solution was $555 \mathrm{~nm}$, and the color was lost upon aeration. The visible color, the $\lambda_{\max }$, and the sensitivity to aeration were compatible with the previously reported properties of reduced BV (2). We concluded that the color which we observed in BV-containing media inoculated with Acholeplasma species was due to reduced BV.

The BV activity was localized in the membrane fraction of $A$. laidlawii B-PG9. The specific activity of the reaction was estimated by determining the increase in $A_{555}$ as the highly colored reduced reaction product was synthesized. The reaction was entirely dependent on NADH. The specific activity of the cytoplasmic fraction was $0.37 A_{555}$ unit $\mathrm{min}^{-1} \mathrm{mg}$ of protein ${ }^{-1}$, while the specific activity of the membrane fraction was 111.1 $A_{555}$ units min $^{-1}$ mg of protein ${ }^{-1}$. The NADH oxidase activity of all Acholeplasma species has also been shown to be localized in the membrane (11).

In preliminary studies (data not shown) we found that broth cultures of the BV-negative isolates Mycoplasma capricolum subsp. capricolum 14, Mycoplasma fermentans $\mathrm{PG} 18^{\mathrm{T}}$, and $U$. urealyticum $\mathrm{T} 960^{\mathrm{T}}$ grown in the presence of BV rapidly became BV positive when $A$. laidlawii B-PG9 was added as a contaminant. This suggests that the BV test may be useful for determining the presence of Acholeplasma species in mixed cultures containing Mollicutes belonging to some other genera.

In other experiments (data not shown), we attempted to use the property of BV reduction by Acholeplasma strains as an indicator of Acholeplasma contamination of tissue cultures. However, the experiments failed because at the concentrations of BV tested ( 0.063 to $4 \mathrm{mM})$, the growth of HeLa cells was inhibited.

The usefulness of the BV-reducing ability of $A$. laidlawii B-PG9 was also tested aerobically on SNE containing $0.9 \%$ Noble agar (Difco) and $1 \mathrm{mM} \mathrm{BV}$. In this test the organism grew, although poorly. No color change was detected. These experiments failed, apparently because of rapid and complete reoxidation of the colored reduction product by air and the apparent toxicity of $\mathrm{BV}$.

\section{DISCUSSION}

Upon one-electron reduction, the essentially colorless compound $\mathrm{BV}$ (or $\mathrm{BV}^{2+}$ ) becomes highly colored $\left(\lambda_{\max }, 555 \mathrm{~nm}\right.$ ) and a singly charged stable free radical (reduced $\mathrm{BV}^{\bullet}$ or $\mathrm{BV}^{2 \bullet}$ ) $(2,10)$. The color rapidly disappears upon aeration. We speculate that the NADH-dependent reduction of $\mathrm{BV}$ by $A$. laidlawii B-PG9 membranes is specifically related to the organism's NADH-dependent membrane-localized NADH oxidase. These properties may be affected by the same protein. The membrane-localized enzyme NADH oxidase is a flavin mononucleotide-copper-containing iron-sulfur protein (15). We hypothesize that the same enzyme or a similar enzyme (i.e., an enzyme with a comparable or lower redox potential) is present in all other Acholeplasma species, but not in all other genera of the Mollicutes.

The NADH oxidase of Mycoplasma capricolum subsp. capricolum is the only other Mollicutes NADH oxidase that has been isolated and characterized (9). This enzyme differs markedly from the $A$. laidlawii enzyme (9). The prosthetic group of the Mycoplasma capricolum subsp. capricolum NADH oxidase is flavin adenine dinucleotide, not flavin mononucleotide. Also, unlike the $A$. laidlawii enzyme, this enzyme has no associated metals, cannot donate electrons to cytochrome $c$, dichloroindolphenol, or ferricyanide, or produce superoxide radicals.

If our hypothesis is correct, the redox potentials of the acho- leplasmal NADH oxidases are similar to the redox potential of the $A$. laidlawii B enzyme (9) and are more negative than the $\mathrm{E}_{0}^{\prime}$ of $\mathrm{BV}$, since the flow of electrons is from more negative to more positive. The $\mathrm{E}_{0}^{\prime}$ of $\mathrm{BV}$ is $-0.359 \mathrm{~V}(22)$. The $\mathrm{E}_{0}^{\prime}$ of the Mycoplasma capricolum subsp. capricolum NADH oxidase is more positive than $-0.359 \mathrm{~V}$, and hence this enzyme is not able to donate electrons to an acceptor like $\mathrm{BV}$, which has a more negative potential.

In preliminary growth curve (CFU) experiments (data not shown), we found that the BV-positive organism $A$. laidlawii B-PG9 died after about $6 \mathrm{~h}$ of incubation in the presence of 1 $\mathrm{mM}$ BV. At this time the level of reduced BV was maximal. We assume that the organism was in a sense "starved" for NADH; that is, as NADH was synthesized by the cells, it was nonenzymatically oxidized by $\mathrm{BV}$, which removed it from the metabolic pool. BV is quickly reoxidized in air and then is able to accept electrons from more NADH as it is synthesized by cells. The organisms become transiently depleted of NADH and die. When the reoxidation is impeded, the colored compound can be detected. Another explanation for the apparent toxicity of BV reduction is based on the results of animal studies and is related to the production of hydrogen peroxide (10). The highly reactive free radical reduced $\mathrm{BV}$ interacts with $\mathrm{O}_{2}$, producing a peroxide that inhibits essential metabolic processes. In the case of BV-negative Mollicutes, such as Mycoplasma capricolum subsp. capricolum and Mycoplasma fermentans, BV appears to be inert.

We also tested methyl viologen (1,1'-dimethyl-4,4'-bipyridinium dichloride or paraquat) in the same way (data not shown). Paraquat has a redox potential $\left(\mathrm{E}_{0}^{\prime}=-0.446 \mathrm{~V}\right)(2)$ that is even more negative than that of $\mathrm{BV}$. Paraquat was also reduced by $A$. laidlawii B-PG9. However, the reduced colored compound ( $\left.\lambda_{\max }, 601 \mathrm{~nm}\right)$ (2) seemed considerably more labile in air than reduced $\mathrm{BV}$, and therefore, this compound was not studied further.

The variable and frequently weaker but positive BV responses that we detected in some cultures of non-Acholeplasma species, especially mesoplasmas, may also have been due to the presence of an NADH oxidase with similar or intermediate properties.

$\mathrm{BV}$ reduction may be associated with the NADH oxidase of acholeplasmas, because the NADH oxidase of the BV-positive Acholeplasma species may act as a diaphorase. Diaphorases are enzymes that are capable of mediating the transfer of electrons from a donor such as $\mathrm{NADH}$, to both unnatural electron acceptors, like BV, tetrazoliums, or ferricyanide, or a natural electron acceptor, such as (presumably) $\mathrm{O}_{2}$. A . multilocale PN525 (7) did not reduce $\mathrm{BV}$. We have shown that the NADH oxidase of this acholeplasma is localized in the cytoplasmic fraction, in contrast to all other acholeplasmas, whose NADH oxidase activities are membrane associated $(11,14)$. The absence of $\mathrm{BV}$ activity in $A$. multilocale $\mathrm{PN} 525^{\mathrm{T}}$ and other BV-negative Mollicutes may be related to a lack of a membrane-localized flavin mononucleotide-copper-containing iron-sulfur-containing NADH oxidase activity that can act as a diaphorase.

We have also reported that $A$. multilocale PN525 $5^{\mathrm{T}}$, unlike all other acholeplasmas, lacks dUTPase, $\mathrm{PP}_{\mathrm{i}}$-dependent phosphofructokinase, and uracil DNA glycosylase activities (5, 12-14, 24). Furthermore, this isolate can use both ATP and $P_{P}$ in the deoxyguanosine kinase reaction (14). This characteristic also distinguishes $A$. multilocale PN525 $5^{\mathrm{T}}$ from all other acholeplasmas, which use either ATP or $\mathrm{PP}_{\mathrm{i}}$ or are completely unable to phosphorylate nucleosides. These findings and the negative $\mathrm{BV}$ response are exceptions to the general metabolic pattern that we have found in 12 Acholeplasma species $(13,14)$. However, the data of Rose et al. indicate that $A$. multilocale 
PN525 ${ }^{\mathrm{T}}$, like other acholeplasmas, has no growth requirement for cholesterol or fatty acids (16). We believe that the lack of a BV response by $A$. multilocale PN525 $5^{\mathrm{T}}$, a member of the only BV-negative Acholeplasma species, coupled with our other findings, indicates that $A$. multilocale PN525 ${ }^{\mathrm{T}}$ belongs to a distinct unrecognized metabolic subgroup of the genus Acholeplasma or is not an Acholeplasma strain.

Our survey is incomplete. We have tested only about $40 \%$ of the 150 species belonging to the class Mollicutes, and therefore, we can only suggest that the simple growth assay used in this study may be useful for distinguishing the BV-negative $M y c o-$ plasma, Spiroplasma, and Ureaplasma species from the BVpositive Acholeplasma species and some other Mollicutes that we have tested. The BV response may have some phylogenetic relevance. We also suggest that the BV test may be useful for determining the presence of Acholeplasma species in broth cultures of other members of the Mollicutes.

\section{ACKNOWLEDGMENTS}

We thank V. V. Hamparian, Viral Diagnostic Laboratory, Childrens Hospital, Columbus, Ohio, for cultures of HeLa cells.

This study was supported by Public Health Service grant RO1A133193 (to J.D.P.) and in part by grant SO6-GM08174 (to J.W.D.) from the National Institutes of Health.

\section{REFERENCES}

1. Aluotto, B. B., R. G. Wittler, C. O. Williams, and J. E. Faber. 1970. Standardized bacteriologic techniques for the characterization of mycoplasma species. Int. J. Syst. Bacteriol. 20:35-58.

2. Anonymous. 1986. Artificial and natural substrates. A. Electron donors, carriers and acceptors, p. 350-355. In R. M. C. Dawson, D. C. Elliott, W. H. Elliott, and K. M. Jones (ed.), Data for biochemical research, 3rd ed. Clarendon Press, Oxford.

3. Bové, J. M., J. C. Vignault, M. Garnier, C. Saillard, O. Garcia-Jurado, C. Bové, and A. Nhami. 1978. Mise en évidence de Spiroplasma citri, l'agent causal de la malade du "stubborn" des agrumes, dans des pervenches (Vinca rosea L.) ornamentales de la ville de Rabat. C. R. Acad. Sci. 286:57-59.

4. Bredt, W. 1976. Estimation of Mycoplasma pneumoniae inoculum size by rate of tetrazolium reduction. J. Clin. Microbiol. 4:92-94.

5. DeSantis, D., V. V. Tryon, and J. D. Pollack. 1989. Metabolism of the mollicutes: the Embden-Meyerhof-Parnas pathway and the hexose monophosphate shunt. J. Gen. Microbiol. 135:683-691.

6. Hackett, K. J. 1986. Cultivation of Drosophila sex-ratio spiroplasma. Science 232:1253-1255.

7. Hill, A. C., A. A. Polak-Vogelzang, and A. F. Angulo. 1992. Acholeplasma multilocale sp. nov., isolated from a horse and rabbit. Int. J. Syst. Bacteriol. 42:513-517.
8. Kirchhoff, H., C. Maass, M. Runge, B. Franz, R. Schmidt, H. Quentmeier, and P. Mühlradt. 1992. Tetrazolium [3-(4,5-dimethylthiazol-2-yl)-2,5-diphenyltetrazolium bromide] reduction by mycoplasmas. Int. J. Syst. Bacteriol. 42:506-508.

9. Klomkes, M., R. Altdorf, and H.-D. Oldenbusch. 1985. Purification and properties of an FAD-containing NADH-oxidase from Mycoplasma capricolum. Biol. Chem. Hoppe-Seyler 366:963-969.

10. Muriana, F. J., and A. M. Relimpo. 1993. Is hydrogen peroxide involved in the benzyl viologen-mediated in-vivo inactivation of rat liver glutamine synthetase? Int. J. Exp. Pathol. 74:219-224.

11. Pollack, J. D. 1975. Localization of reduced adenine nicotinamide adenine nucleotide oxidase activity in Acholeplasma and Mycoplasma species. Int. J. Syst. Bacteriol. 25:108-113.

12. Pollack, J. D. 1995. Methods for testing metabolic activities in Mollicutes, p. 277-286. In J. G. Tully and S. Razin (ed.), Molecular and diagnostic procedures in mycoplasmology, vol. 1. Academic Press, New York.

13. Pollack, J. D., M. V. Williams, J. Banzon, K. Donelson, M. A. Jones, L. Harvey, and J. G. Tully. 1994. Comparative metabolism of Mesoplasma, Entomoplasma, Acholeplasma, and Mycoplasma. IOM Lett. 3:167.

14. Pollack, J. D., M. V. Williams, J. Banzon, K. Donelson, M. A. Jones, L. Harvey, and J. G. Tully. 1996. Comparative metabolism of Mesoplasma, Entomoplasma, Acholeplasma, and Mycoplasma. Int. J. Syst. Bacteriol. 46: 885-890.

15. Reinards, R., J. Kubicki, and H.-D. Oldenbusch. 1981. Purification and characterization of NADH oxidase from membranes of Acholeplasma laidlawii, a copper-containing iron-sulfur flavoprotein. Eur. J. Biochem. 120: 329-337.

16. Rose, D. L., J. G. Tully, J. M. Bové, and R. F. Whitcomb. 1993. A test for measuring growth responses of mollicutes to serum and polyoxyethylene sorbitan. Int. J. Syst. Bacteriol. 43:527-532.

17. Senterfit, L. B. 1983. Tetrazolium reduction, p. 377-378. In S. Razin and J. G. Tully (ed.), Methods in mycoplasmology, vol. 1. Academic Press, New York.

18. Senterfit, L. B., and K. E. Jensen. 1966. Antimetabolic antibodies to Mycoplasma pneumoniae measured by tetrazolium reduction inhibition. Proc. Soc. Exp. Biol. Med. 122:786-790.

19. Somerson, N. L., and H. E. Morton. 1953. Reduction of tetrazolium salts by pleuropneumonialike organisms. J. Bacteriol. 65:245-251.

20. Subcommittee on the Taxonomy of the Mycoplasmatales. 1979. Proposal of minimal standards for descriptions of new species of the class Mollicutes. Int. J. Syst. Bacteriol. 29:172-180.

21. Tully, J. G., and S. Razin. 1977. The Mollicutes: acholeplasmas, spiroplasmas, thermoplasmas, and anaeroplasmas, p. 445-459. In A. I. Laskin and H. Lechevalier (ed.), Handbook of microbiology, vol. 1. CRC Press, Cleveland.

22. Wardman, P. 1991. The reduction potential of benzyl viologen: an important reference compound for oxidant/radical redox couples. Free Radical Res. Commun. 14:57-67.

23. Whitcomb, R. F. 1983. Culture media for spiroplasmas, p. 147-158, In S. Razin and J. G. Tully (ed.), Methods in mycoplasmology, vol. 1. Academic Press, New York.

24. Williams, M. V., and J. D. Pollack. 1985. Pyrimidine deoxyribonucleotide metabolism in members of the class Mollicutes. Int. J. Syst. Bacteriol. 35: $227-230$. 